\title{
Epidemiology and Management of Hepatocellular Carcinoma
}

\author{
Ju Dong Yang, MD and Lewis R. Roberts, MBChB, PhD* \\ Miles and Shirley Fiterman Center for Digestive Diseases, Division of Gastroenterology and \\ Hepatology, College of Medicine, Mayo Clinic, 200 First Street South West, Rochester, MN \\ 55905, USA
}

\section{Keywords}

Hepatitis B; Hepatitis C; Pathogenesis; Liver transplantation; Transarterial chemoembolization; Radiofrequency ablation

\section{EPIDEMIOLOGY}

\begin{abstract}
Hepatocellular carcinoma (HCC) is the seventh most common cancer and the third leading cause of cancer-related death worldwide, with an estimated 748,000 new liver cancer cases and 696,000 liver cancer deaths caused in 2008, which increased from 626,000 incident liver cancers and 598,000 deaths in 2002. ${ }^{1}$ The incidence of HCC varies across the world. More than $80 \%$ of HCCs develop in Asian and African countries, where between $40 \%$ and $90 \%$ of HCCs are attributable to chronic hepatitis B (Fig. 1). ${ }^{2,3}$ The incidence of HCC in the United States and Europe is relatively low and up to two-thirds of HCCs in these regions are attributable to chronic hepatitis $\mathrm{C}$ virus (HCV) infection (see Fig. 1). ${ }^{3}$ The incidence of HCC has been rapidly increasing in Western countries because of the increased prevalence of $\mathrm{HCV}$ infection contracted within the 20 to 40 years before testing for $\mathrm{HCV}$ was available. In the United States, the incidence of HCC has tripled, from 1.6 per 100,000 in 1975 to 4.9 per 100,000 in $2005 .{ }^{4}$ It is expected that the incidence of HCC will continue to increase in the next decade because of the 20 to 40 year lag time between virus acquisition and the development of HCC and the peak incidence of HCV infection in the 1980s. ${ }^{5}$ HCC is 2 to 4 times more frequent in men than in women. Exposure to hepatocarcinogens and a higher prevalence of hepatitis infection partially explain this gender difference; however, intrinsic protection of women, which has been partially attributed to suppression of interleukin (IL)-6 signaling by estrogens and increased androgen receptor signaling in men, seems to contribute to the gender difference in the risk of HCC. ${ }^{6-8}$ In Western countries where HCV and hepatitis B virus (HBV) infection are typically acquired in adolescence, early adulthood, or later, $\mathrm{HCC}$ rarely develops before the age of 45 years, but incidence rates continue to increase with age. ${ }^{9}$ However, in Africa and Asia, because of the early exposure to hepatitis viruses and hepatocarcinogens such as dietary aflatoxins, HCC tends to develop at an earlier age.
\end{abstract}

\footnotetext{
(c) 2010 Elsevier Inc. All rights reserved.

"Corresponding author: Roberts.lewis@ mayo.edu.

Financial disclosure: This work was supported by grant no. CA100882 from the National Institutes of Health.
} 


\section{CAUSES OF HCC}

\section{Chronic Hepatitis B}

Chronic HBV infection is the most common cause of HCC. Mother-to-infant vertical transmission is the usual route of HBV acquisition in HBV hyperendemic regions in Asia, whereas horizontal transmission in early life is most frequent in Africa. In the United States and other Western countries, where the prevalence of HBV infection is low, it is usually acquired through high-risk behaviors such as intravenous drug use, sexual exposure, or iatrogenically through blood transfusion, hemodialysis, or organ transplantation.

Causal associations between HBV and HCC have been shown in several studies. In a population-based, large, prospective study of 22,708 Taiwanese men with 8.9 years of follow-up, the incidence of HCC was 98.4 times higher in HBV carriers than in noncarriers. ${ }^{10}$ The overall incidence of HCC in hepatitis B carriers seems to depend on race/ ethnicity. In one prospective study from Canada of 1069 hepatitis B carriers (71\% Asian) with 26 months of follow-up, the incidence of HCC was $0.47 \%$ per year. ${ }^{11}$ However, in another study of 371 asymptomatic hepatitis B carriers, most of whom were French Canadian, no HCCs developed in 16 years of follow-up. ${ }^{12}$ White hepatitis B carriers tend to develop HCC at an older age in a background of underlying liver cirrhosis, whereas Asians and Africans tend to develop HCC at a relatively early age with less cirrhotic change of the liver. This difference seems to be caused by the difference in age at which HBV infection is acquired in the different populations. The risk of $\mathrm{HCC}$ is much higher in patients who are hepatitis B e antigen ( $\mathrm{HBeAg}$ ) positive than in those who are hepatitis B surface antigen (HBsAg) positive but HBeAg negative. ${ }^{13-15}$ In a large, prospective study of 11,893 Taiwanese men with a mean follow-up of 10 years, compared with those who were both $\mathrm{HBeAg}$ and $\mathrm{HBsAg}$ negative, the relative risk for $\mathrm{HCC}$ was 9.6 for individuals who were positive for $\mathrm{HBsAg}$ alone and 60.2 for individuals who were positive for both $\mathrm{HBsAg}$ and HBeAg. ${ }^{15}$ The HBV DNA level also influences the risk of HCC. In a large, prospective study of 3653 patients with a mean of 11.4 years follow-up, the HBV DNA level was significantly correlated with the incidence of HCC. ${ }^{16}$ A previous history of HBV infection ( $\mathrm{HBsAg}-, \mathrm{HBcAb}+$ ) also increases the risk of HCC. In patients with $\mathrm{HCC}$ who were HBsAg negative, $29 \%$ had detectable HBV DNA in either serum or liver tissue. Previous HBV infection was the only risk factor for HCC in $12 \%$ of the patients. ${ }^{17}$

HBV has a circular DNA genome that encodes structural and replicative proteins, and contains DNA regulatory elements. After entry into the hepatocyte, viral messenger RNAs are transcribed and translated into viral proteins. New viral genomic DNA is also synthesized by reverse transcription from viral messenger RNA. These new viral genomes, core protein, and polymerase assemble into the complete structures called Dane particles, which are released from the hepatocyte. Viral DNA is able to integrate into host genomic DNA in infected hepatocytes during this process. HBV infection results in chronic inflammation of the liver with the release of inflammatory cytokines that induce liver fibrosis and enhance cell proliferation and the generation of genotoxic reactive oxygen species. Rapid cell cycling of hepatocytes within this oncogenic microenvironment facilitates carcinogenesis. ${ }^{18}$ Integration of viral DNA into the host genome may itself generate genomic instability. ${ }^{19}$ HBV DNA may insert into or adjacent to cellular genes that encode proteins important in carcinogenesis. ${ }^{20-23}$ The hepatitis B X gene encodes an important oncogenic viral protein. HBx protein transactivates cellular promoters through protein-protein interactions, ${ }^{24}$ leading to activation of oncogenic signaling pathways. HBx can also modulate proteasome and mitochondrial function and calcium homeostasis, resulting in effects on cell proliferation and viability (Fig. 2). ${ }^{25-28}$ The HBV preS2 and S proteins may also enhance cell proliferation. ${ }^{29}$ 


\section{Chronic Hepatitis C}

$\mathrm{HCV}$ is the most common blood-borne infection and the leading cause of chronic liver disease and HCC in the United States. ${ }^{30}$ The incidence of HCV-related HCC has tripled in the past 40 years. ${ }^{31} \mathrm{HCV}$ is commonly acquired through direct exposure to blood. Needle sharing during injection drug use and intranasal cocaine use seem to be the most common routes of HCV infection. ${ }^{30}$ Individuals with multiple sexual contacts are at increased risk of $\mathrm{HCV}$ infection, but transmission rates between individuals in monogamous sexual relationships are low. ${ }^{30}$ Blood transfusion used to account for $15 \%$ to $20 \%$ of $\mathrm{HCV}$ infection, but is now less than $0.03 \%$ per unit transfused since the implementation of donor blood screening for HCV in 1994. ${ }^{32,33}$ Vertical transmission from mother to infant occurs in less than $10 \%$ of cases; a high HCV titer in the mother increases the frequency of $\mathrm{HCV}$ transmission. ${ }^{34,35}$

In a large population-based study of 12,008 Taiwanese men with a mean follow-up of 9.2 years, a 20 -fold increased risk of $\mathrm{HCC}$ was found in anti-HCV-positive compared with antiHCV-negative individuals. ${ }^{36}$ Concomitant heavy alcohol use, diabetes mellitus, latent HBV infection, older age, black race, lower platelet count, high alkaline phosphatase, presence of varices, and smoking seem to increase the risk of $\mathrm{HCV}$-induced HCC. ${ }^{37-41}$

HCV is a positive-sense RNA virus with a 9400-nucleotide RNA. It has structural and nonstructural genes that encode at least 10 different proteins. There are at least 6 major $\mathrm{HCV}$ genotypes. Frequent mutation of HCV genomic RNA because of an error-prone RNA polymerase enables $\mathrm{HCV}$ to escape host immune responses, resulting in persistent viral infection. ${ }^{42} \mathrm{HCV}$ causes chronic liver inflammation with increased oxidative stress, leading to cycles of death and regeneration of hepatocytes. In this context of increased cell turnover and reactive oxygen species, hepatocytes are susceptible to genetic mutations. The accumulation of these genetic changes eventually results in malignant transformation of hepatocytes. In addition to this indirect role of $\mathrm{HCV}$ in carcinogenesis, viral proteins seem to play direct roles in promoting tumorigenesis. The core, NS3, NS4B, and NS5A proteins have been implicated in apoptosis, signal transduction, transcriptional activation, and cellular transformation (see Fig. 2). ${ }^{28,43-45}$

\section{Chronic Hepatitis and Cirrhosis}

The incidence of HCC among cirrhotic patients is $2 \%$ to $4 \%$ per year. ${ }^{46,47}$ Alcoholic liver disease is the most common cause of liver cirrhosis other than viral hepatitis. In a large case control study, alcohol intake increased the risk of $\mathrm{HCC}$ in a linear manner and this risk was greater in patients with viral hepatitis. ${ }^{48}$ Cirrhosis from nonalcoholic steatohepatitis is emerging as a major risk factor for HCC. Primary biliary cirrhosis, genetic hemochromatosis, autoimmune hepatitis, and a1-antitrypsin deficiency are less common, but important, risk factors for liver cirrhosis and HCC. ${ }^{49,50}$

\section{Other Risk and Protective Factors}

A case control study suggested that hypothyroidism is more frequent in patients with HCC with an unknown cause than in patients with $\mathrm{HCC}$ with a known cause ${ }^{51}$ Recently, a larger study confirmed a significant association between hypothyroidism and HCC in women, with an adjusted odds ratio (OR) of 2.9.52

Coffee consumption has a protective effect from HCC. A meta-analysis estimated that 2 or more cups of coffee per day results in a $43 \%$ risk reduction for HCC. ${ }^{53}$ In a recent large case control study, statin use also showed a protective effect against HCC in a diabetic population with an adjusted OR of $0.74 .^{54}$ 


\section{Preventive Measures}

Prevention of HBV infection is the most effective measure to prevent HBV-induced HCC. Universal vaccination was implemented in 164 out of 190 World Health Organization member states as of 2006, and has resulted in dramatic decreases in the incidence of HBV infection. After the introduction of HBV vaccination in 1984, the prevalence of HBsAg+ carrier status in Taiwanese children younger than 15 years old decreased from $9.8 \%$ in 1984 to $0.7 \%$ in $1999 .{ }^{55}$ At the same time, the incidence of HCC in Taiwanese children decreased by $50 \%$ from 0.7 per 100,000 between 1981 and 1986 to 0.36 per 100,000 between 1990 and $1994 .{ }^{56}$ Recently, a large population-based study in Taiwan has shown that the age- and sexadjusted relative risk for HCC was 0.31 among children aged 6 to 19 years in vaccinated, compared with unvaccinated, birth cohorts. ${ }^{57}$ Global vaccination of newborns, especially in HBV-hyperendemic populations, should lead to a substantial reduction in the incidence of HBV-related HCC within the next few decades.

For patients who have already contracted chronic $\mathrm{HBV}$ infection, it is important to avoid modifiable risk factors. ${ }^{37,41}$ It seems that the risk of $\mathrm{HCC}$ is decreased in patients responding to treatment with interferon (INF) ${ }^{58-60}$ In a large, prospective, randomized, controlled trial of 651 patients with a median follow-up of 32 months, lamivudine decreased progression from cirrhosis to HCC with a hazard ratio of $0.49(P=.047){ }^{61}$ Risk reductions for HCC have been also observed in patients with HBV without cirrhosis in several case control studies. ${ }^{62,63}$

There is no vaccination available for $\mathrm{HCV}$, partly because of its high propensity for genomic mutation during viral replication. Therefore, it is important to avoid modifiable risk factors for HCC. Studies investigating the role of antiviral treatment of HCV in the prevention of HCC in cirrhotic patients have been inconclusive. In a prospective, randomized, controlled trial of 90 patients with $\mathrm{HCV}$-related cirrhosis with an average of 8.2 years of follow-up, HCC developed in $73 \%$ of untreated, but in only $27 \%$ of INF-treated, patients. ${ }^{64}$ Multiple other retrospective studies and several meta-analyses have reached similar conclusions. The magnitude of the effect seems to be largest in sustained responders. ${ }^{65,66}$ In contrast, prospective controlled trials from France and Italy showed no evidence that INF monotherapy decreases the risk of HCC among patients with HCV-related cirrhosis. ${ }^{67,68}$ INF treatment in patients with HCV who are noncirrhotic seems to decrease the risk for HCC. In a large, retrospective Japanese study of 2890 patients with chronic HCV with 4.3 years of follow-up, the incidence of HCC in patients treated with INF was $1.1 \%$ per year, compared with $3.1 \%$ per year in the untreated group. This effect was most significant among patients responding to INF and those with stage 2 and 3 fibrosis. ${ }^{69}$ There has been a question whether INF treatment may reduce the risk for HCC because of its antiproliferative action, even in patients who do not achieve sustained virologic responses; however, the Hepatitis C Antiviral Long-term Treatment Against Cirrhosis (HALT-C) Trial has recently shown that long-term maintenance therapy with pegylated INF does not decrease the risk for HCC in patients with advanced liver fibrosis. ${ }^{40,70}$

\section{CLINICAL FEATURES OF HCC}

Aside from symptoms related to chronic liver disease, patients are usually asymptomatic at HCC diagnosis. Active surveillance for HCC in high-risk populations has increased the frequency of diagnosis of HCC in asymptomatic patients. Symptoms occurring in patients with advanced disease include abdominal pain, weight loss, pleuritic chest pain from subcapsular masses, or bone pain from distant metastases. HCC development may result in rapid worsening of liver function because of replacement of functioning liver tissue or invasion of the portal vein. Increased ascites, spontaneous bacterial peritonitis, variceal bleeding, jaundice, and hepatic encephalopathy should therefore raise the suspicion for 
HCC. Intra-abdominal hemorrhage from ruptured HCC or paraneoplastic syndromes manifesting as hypoglycemia, erythrocytosis, or hypercalcemia are uncommon. Physical examination usually shows signs of cirrhosis with portal hypertension, including spider angiomas, jaundice, gynecomastia, palmar erythema, ascites, and caput medusae. A bruit is occasionally present over the liver because of the highly vascular nature of HCCs.

Laboratory findings are usually nonspecific. Anemia, thrombocytopenia, and abnormal liver tests are commonly found.

\section{DIAGNOSIS OF HCC}

\section{Surveillance}

Regular surveillance is recommended for individuals at high risk for HCC development (Table 1). In a randomized controlled trial of 18,816 Chinese patients with chronic hepatitis, surveillance for HCC with ultrasound (US) and serum a-fetoprotein (AFP) level every 6 months increased the detection of small HCCs, the frequency of surgical resection, and improved overall survival with a mortality reduction of $37 \% .{ }^{71}$ US examination is the most important screening tool for HCC. Despite several limitations of US, such as operatordependent interpretation, poor diagnostic performance in obese patients, and impaired detection of nodules in the cirrhotic liver, its sensitivity and specificity are $65 \%$ to $80 \%$ and $90 \%$ respectively. ${ }^{72}$ One retrospective study has reported no difference in HCC stage at detection and 5-year survival between groups undergoing US surveillance at intervals of 6 versus 12 months; however, most hepatologists use a 6-month interval. ${ }^{73}$ The routine use of computed tomography (CT) in place of US for surveillance is not recommended because of the high cost and repeated radiation and contrast exposure. However, screening by CT was associated with the greatest gain in life expectancy in patients on a waiting list for liver transplantation. ${ }^{74}$ The serum AFP level is used for surveillance in combination with US in most high-incidence countries. In one study, at a cutoff value of $20 \mathrm{ng} / \mathrm{mL}$, the sensitivity of AFP was $60 \%$, with a specificity of $90.6 \%$. With a cutoff value of $200 \mathrm{ng} / \mathrm{mL}$, the specificity of AFP increased to $99.4 \%$, but sensitivity dropped to $22.4 \% .^{75}$ Therefore, the use of AFP alone for HCC surveillance is discouraged. Other tumor markers such as des- $\gamma-$ carboxyprothrombin (DCP) and lectin-bound AFP (AFP-L3) are used in Asia as adjunctive diagnostic and prognostic markers to AFP because of their correlation with tumor size and high specificity respectively. However, their routine use for surveillance is not yet formally recommended in Europe and North America. A recent multi-center study in the United States has shown that AFP had the best area under the receiver operating characteristic curve for early-stage HCC, followed by DCP and AFP-L3\% and suggested an optimal cutoff value of $10.9 \mathrm{ng} / \mathrm{mL}$ (sensitivity of $66 \%$ and specificity of $82 \%$ ) for surveillance. ${ }^{76}$

\section{DIAGNOSTIC APPROACH TO HCC}

Triple phase contrast-enhanced helical CT or dynamic magnetic resonance imaging (MRI) are the diagnostic modalities of choice once suspicious lesions are found by surveillance US. The presence of arterial enhancement followed by portal venous washout has an overall sensitivity and specificity of $90 \%$ and $95 \%$ respectively, with a specificity of $98 \%$ for lesions greater than $2 \mathrm{~cm}$ in size. The overall performance of MRI is slightly better than CT. ${ }^{77}$

The American Association for the Study of Liver Diseases has recommended a diagnostic approach for HCC that depends on lesion size (Fig. 3) ${ }^{78}$ If a new lesion in a cirrhotic liver is larger than $2 \mathrm{~cm}$, the presence of arterial enhancement followed by portal venous washout on 1 dynamic imaging modality is diagnostic for HCC. An AFP more than $200 \mathrm{ng} / \mathrm{mL}$ may substitute for dynamic imaging criteria. For lesions between 1 and $2 \mathrm{~cm}$ in a cirrhotic liver, characteristic imaging findings are less reliable and should be present on both CT and MRI 
scans to diagnose HCC. If the lesion is smaller than $1 \mathrm{~cm}$, it should be followed with US at intervals of 3 to 6 months. If there is no change in the lesion during a close follow-up period of 2 years, patients can return to routine surveillance.

Percutaneous liver biopsy is indicated when dynamic imaging modalities show inconclusive results. Specifically, biopsy is usually required when lesions $(>1 \mathrm{~cm})$ develop without background liver cirrhosis, lesions are larger than $2 \mathrm{~cm}$ without a characteristic vascular profile on either of the dynamic imaging studies with AFP less than $200 \mathrm{ng} / \mathrm{mL}$, or the lesions are between 1 and $2 \mathrm{~cm}$ and show an inconsistent vascular profile on 2 dynamic imaging studies. The sensitivity of US-guided percutaneous needle biopsy has been reported to be $90 \% .{ }^{79}$ Therefore, a negative result from percutaneous liver biopsy does not rule out HCC. Close follow-up of such lesions at 3- to 6-month intervals is required until the nodules disappear or acquire the typical radiologic features of HCC. There is a risk of biopsy complications such as bleeding or seeding of tumor along the needle track. ${ }^{80} \mathrm{~A}$ recent metaanalysis has reported that the incidence of needle track tumor seeding is $2.7 \%$ overall, or $0.9 \%$ per year after biopsy. ${ }^{81}$ Therefore, percutaneous biopsy should be used with caution and due consideration, particularly in patients who are eligible for curative therapies.

\section{TREATMENT APPROACH FOR HCC}

\section{Stage of HCC}

HCC staging systems usually include tumor characteristics such as tumor size, number, vascular invasion and metastasis. The severity of underlying liver disease is also incorporated in some models because of the effect of cirrhosis with portal hypertension on survival of patients with HCC. The tumor, node, metastasis (TNM); Barcelona Clinic Liver Cancer (BCLC), Cancer of the Liver Italian Program (CLIP), and Japan Integrated Scoring System (JIS) are the most widely used staging systems for HCC (Table 2). TNM staging classifies patients into 4 groups based on tumor size, number, lymph node, vascular invasion, and distant metastasis. Its role in the prediction of survival has been validated in a large cohort of patients undergoing liver transplantation. ${ }^{82}$ TNM staging does not account for the severity of underlying chronic liver disease, which is a major prognostic factor in patients who are not eligible for curative treatment. The CLIP score incorporates severity of liver disease (Child-Turcotte-Pugh score) and tumor characteristics (tumor morphology, AFP, portal vein thrombosis) and classifies patients with HCC into 6 groups. This system is useful for patients undergoing nonsurgical treatment, but provides limited stratification of patients with early-stage HCC. ${ }^{83,84}$

The BCLC staging system classifies patients into 5 groups based on tumor characteristics, severity of liver disease and performance status, and cancer-related symptoms to predict prognosis and guide the treatment approach (Fig. 4). The performance of the BCLC system has been validated in several independent studies. ${ }^{85,86}$ The biggest advantage of this system is its ability to link stage of HCC to a recommended treatment modality. Very early HCC can be treated with resection or radiofrequency ablation (RFA) depending on tumor location and medical comorbidities. Patients with early-stage HCC are eligible for resection, ablation, or liver transplantation. Intermediate-stage HCCs are managed by palliative transarterial chemoembolization (TACE) or radioembolization. Sorafenib is the only available FDA-approved treatment for patients with advanced-stage HCC and symptomatic management is most appropriate in patients with terminal-stage HCC.

\section{Surgical Resection}

Surgical resection is a potentially curative treatment for HCC. Resection is restricted to patients without cirrhosis or those with cirrhosis and well-preserved liver function because of the risk of liver decompensation after resection. In Asian countries, the indocyanin green 
retention test is performed to assure the safety of surgical resection. In Western countries, clinical assessment of portal hypertension and bilirubin are used to confirm candidacy for surgical resection. A hepatic vein pressure gradient less than $10 \mathrm{~mm} \mathrm{Hg}$ and normal serum bilirubin level were the best predictors of a good outcome after surgery. No decompensation was found in this group and the 5-year survival was greater than $70 \% .87,88$ In contrast, most patients with significant portal hypertension and normal bilirubin developed postoperative decompensation with a 5-year survival of less than 50\%. Patients with portal hypertension and an increased serum bilirubin level had a 5-year survival of less than $30 \%$. Clinically significant portal hypertension can also be presumed from the presence of thrombocytopenia (platelet count $<100,000$ ) and splenomegaly. Therefore, resection is considered in patients with a normal bilirubin and a platelet count higher than 100,000 without varices or other signs of clinically significant portal hypertension. A Model for End-Stage Liver Disease (MELD) score of 8 or less is functionally equivalent to these criteria. ${ }^{89}$

Resection is recommended for single tumors or multiple tumors confined to 1 lobe of the liver. In a study of 12,118 Japanese patients with HCC, the 5-year survival was 57\% after resection of a single lesion, $45 \%$ for patients with 2 lesions, and $26 \%$ in patients with 3 or more lesions. ${ }^{90}$ Five-year survival after resection decreased as tumor size increased, with a range of $53 \%$ to $66 \%$ for tumors less than $5 \mathrm{~cm}$, and $32 \%$ to $38 \%$ for tumors larger than 5 $\mathrm{cm} .{ }^{90}$ Because some tumors with less aggressive biology present as a single large lesion without microvascular invasion, the size of the tumor alone should not preclude surgical resection. In patients with cirrhosis, the remaining liver continues to be at risk of development of cancer after surgical resection, and the risk of recurrence at 5 years exceeds $70 \% .{ }^{91}$ Microvascular invasion is a strong predictor of recurrence. ${ }^{92}$ A narrow resection margin also increases the risk of recurrent $\mathrm{HCC} .{ }^{93}$ There is no known adjuvant treatment that decreases the risk of tumor recurrence after resection.

\section{Liver Transplantation}

Liver transplantation is the most definitive treatment of HCC because it removes not only the malignancy but also the underlying diseased liver with its high risk of recurrence. The selection criteria for liver transplantation were initially broad and patient outcomes were poor, with 5-year survival of less than $20 \% . .^{94,95}$ This rate changed after adoption of the Milan criteria for selection of candidates with HCC for liver transplantation, which restrict transplantation to patients with 1 tumor $5 \mathrm{~cm}$ or less in diameter or up to 3 lesions with the largest no more than $3 \mathrm{~cm}$ in diameter. These criteria resulted in 4-year overall survival and recurrence-free survival rates of $75 \%$ and $83 \%$ respectively after liver transplantation, making long-term survival of patients transplanted for HCC similar to that of patients receiving liver transplants for non-HCC indications. ${ }^{96}$ Among patients who met the Milan criteria on pathologic examination of the explanted liver, the 4-year overall survival and recurrence-free survival rates increased to $85 \%$ and $92 \% .{ }^{96}$ The University of California in San Francisco (UCSF) has proposed expanded selection criteria for liver transplantation. ${ }^{97}$ The UCSF criteria (1 tumor no more than $6.5 \mathrm{~cm}$ or up to 3 lesions with each lesion no more than $4 \mathrm{~cm}$ with a total tumor diameter $8 \mathrm{~cm}$ or less) are more inclusive but maintain a $75 \%$ 5 -year survival comparable with the overall survival with Milan criteria. The UCSF criteria are yet to be implemented by the United Network for Organ Sharing (UNOS), except on appeal as an exception to standard criteria. For patients with HCC meeting UNOS criteria for liver transplantation, a MELD exception score, which is based on the probability of death within 3 months, is awarded so that transplantation can be accomplished in a reasonable timeframe. Patients receive a MELD score of 22 unless their calculated MELD is greater. Patients with HCC receive additional MELD points every 3 months while on the waiting list because of the increased risk of pretransplantation mortality. 
For HCCs initially beyond UNOS criteria, downstaging using local or locoregional therapy has been used to decrease the size or number of tumors into the range of the UNOS criteria to allow listing for liver transplantation. ${ }^{98-100}$ This approach has achieved some success with reduction of the tumor size and number in $70 \%$ of patients, eventually resulting in successful liver transplantation in 53\% of patients with an intention-to-treat survival of $81.8 \%$ at 2 years among 30 patients. ${ }^{99} \mathrm{~A}$ validation study with a larger sample size and longer follow-up has shown similar rates of success in downstaging tumors (70\%) and in achieving liver transplantation (57.4\%), with an intention-to-treat survival of $69.3 \%$ at 4 years. ${ }^{100}$

Living donor liver transplantation (LDLT) entails a significant morbidity and mortality to donors. ${ }^{101}$ In spite of the known donor risk, given the shortage of deceased donors, LDLT has been used to shorten the waiting time or broaden the selection criteria for liver transplantation. This treatment modality may be effective for selected patients given that tumor progression beyond UNOS criteria or death while on a waiting list results in a cumulative dropout rate of $15 \%$ to $25 \%$ at 12 months. ${ }^{102}$

\section{Percutaneous Ablation}

Percutaneous ablation is effective for treatment of small tumors in patients who are not eligible for liver transplantation or resection. In percutaneous ethanol injection (PEI), ethanol is injected directly into the tumor under US guidance. PEI has an excellent treatment effect, resulting in complete necrosis of small tumors; however, as the tumor nodule gets larger, the treatment effect is impaired because the injected ethanol cannot access the entire volume of tumor. As a result, the necrosis rate decreases from $90 \%$ to $100 \%$ for HCCs smaller than $2 \mathrm{~cm}$ to $70 \%$ for tumors between 2 and $3 \mathrm{~cm}$, and $50 \%$ for tumors between 3 and $5 \mathrm{~cm} .{ }^{103-105}$

For RFA, an electrode is inserted into the tumor and excited by a radiofrequency generator, thus delivering heat into the tumor and leading to tumor necrosis. RFA is now more frequently used than PEI because of the ability to completely ablate larger tumors in fewer treatment sessions. Several randomized controlled trials have reported that RFA has better efficacy than PEI. ${ }^{106,107}$ In a randomized controlled trial of treatment of HCCs less than 4 $\mathrm{cm}$ in size, RFA was superior to PEI in rate of complete tumor necrosis (96\% in RFA vs $88 \%$ in PEI), 3 year overall survival (62\%-78\% in RFA vs 36\%-72\% in PEI), and recurrence-free survival (34\%-49\% in RFA vs $12 \%-43 \%$ in PEI). ${ }^{107}$ RFA seems to have similar efficacy to surgical resection in the treatment of very early-stage HCCs, with a lower complication rate and cost. ${ }^{108-110}$

\section{TACE}

TACE is a dual treatment process that includes (1) intraarterial delivery of chemotherapeutic agent(s) directly into the tumor, and (2) embolization of the hepatic artery that feeds the tumor. TACE is currently recommended in patients with large multifocal HCCs and preserved liver function without cancer-related symptoms, vascular invasion, or metastasis. Patients with poor liver function or portal vein thrombosis are not candidates because of the high risk of acute liver decompensation, which occurs after $20 \%$ of sessions and is irreversible in $3 \%$ of cases. ${ }^{111}$ Randomized controlled trials have shown the benefit of TACE in selected patients with unresectable HCC. ${ }^{112,113}$ The TACE groups had better overall survival than the conservative management groups (2-year survival of 31\%-64\% and $11 \%-27 \%$ in the TACE and control groups respectively). In a prospective cohort study of 8510 patients who underwent TACE for unresectable HCC, median survival was 34 months with a 5-year overall survival of $26 \% .{ }^{114}$ TACE is also used in patients with early-stage HCC when ablative treatment cannot be safely performed because of the tumor location. 
TACE is frequently used for downsizing the tumor or as a bridging treatment before liver transplantation. ${ }^{99,115}$ An additive effect of TACE to RFA has been reported, but a recent randomized controlled trial with 89 patients with a single HCC nodule less than $3 \mathrm{~cm}$ showed no additive effect of TACE compared with RFA alone. ${ }^{116-118}$ Post-embolization syndrome is the most common complication of TACE and results in abdominal pain, nausea, vomiting, and fever caused by hepatic arterial occlusion and tumor ischemia.

Postembolization syndrome usually resolves within a week with conservative management. The treatment effect of TACE is evaluated by comparison of vascular enhancement of the tumor in dynamic imaging studies rather than tumor size because most tumor nodules do not decrease in size even after successful treatment. ${ }^{19,120}$ TACE may be repeated at 2- to 6month intervals if there is tumor progression. ${ }^{121}$

\section{Radionuclide Yttrium 90 Radioembolization}

Delivery of yttrium 90-impregnated glass microspheres (TheraSphere) or resin beads (SirSphere) by transarterial radioembolization (TARE) has been shown to be effective in patients with intermediate- to advanced-stage HCC (Fig. 5). ${ }^{12-124}$ Potential radiation exposure to the gastrointestinal tract is managed by embolization of hepatic artery branches to the stomach or small intestine. Lung exposure is assessed by infusion of technetium 99 macroaggregated albumin into the hepatic artery followed by a radionuclide scan before treatment to identify candidates with significant intratumoral vascular shunting that precludes radioembolization. Additional randomized studies are required to evaluate the long-term efficacy and side effect profile of TARE.

\section{Systemic Chemotherapy and Targeted Treatments}

Most HCCs are resistant to chemotherapeutics and patients usually have poor tolerance of systemic chemotherapy because of the underlying portal hypertension with resultant pancytopenia. Hence, there have been sustained efforts to understand the basic molecular pathogenesis of HCC to develop targeted therapies. Molecular pathways implicated in liver carcinogenesis include receptor tyrosine kinases, Wnt/ $\beta$-catenin, ubiquitin-proteasome, epigenetic promoter methylation and histone acetylation, PI3 kinase/AKT/MTOR, proangiogenic molecules, and telomerase. ${ }^{125}$ Sorafenib, an oral multikinase inhibitor that targets the Raf kinase, vascular endothelial growth factor receptor, and platelet-derived growth factor receptor signaling pathways involved in tumor cell proliferation and angiogenesis (Fig. 6), is the only agent currently approved for treatment of advanced HCC. In a multicenter, randomized, placebo-controlled trial of 602 patients with advanced HCC, overall survival was 10.7 months in the sorafenib group compared with 7.9 months in the placebo group: a highly significant difference. ${ }^{126}$ Median time to progression was 5.5 months in the sorafenib group and 2.8 months in the placebo group. Diarrhea, hypertension, and hand-foot skin reaction are the most significant side effects.

\section{SUMMARY}

Chronic hepatitis B and C remain the most important risk factors for HCC. Primary prevention of $\mathrm{HBV}$ and $\mathrm{HCV}$ infection is the most effective way to decrease the worldwide disease burden of HCC. Global vaccination of infants against HBV will eventually decrease the incidence of HBV-related HCCs. A decreased incidence of transfusion-related HCV infection and increased awareness of the risks of behaviors such as needle sharing, intranasal cocaine use, and nonsanitary injection practices will contribute to the decreased incidence of HBV- and HCV-related HCC.

The incidence of HCC is expected to continue to increase for the next several years. New antivirals that can effectively treat chronic viral hepatitis will be important for the prevention 
of HCC in patients with chronic HBV or HCV infections. In spite of much effort directed toward the early detection of HCC, it is still diagnosed at an advanced stage in most cases. Continued efforts are needed to improve the early detection of HCC through development of new tumor markers or imaging tools and by encouraging more widespread implementation of existing surveillance modalities, particularly ultrasonography. Liver transplantation, surgical resection, and RFA are effective therapies for early-stage HCC. Recent advances in understanding molecular and signaling pathways in hepatocarcinogenesis have ushered in a new era of targeted therapies for treatment of HCC. The hope is that the convergence of advances in cancer biology and therapeutic technologies will eventually result in the development of highly effective therapies against intermediate- to advanced-stage HCC.

\section{Acknowledgments}

Secretarial support from Victoria Campion is gratefully acknowledged.

\section{References}

1. Yang JD, Roberts LR. Hepatocellular carcinoma: a global view. Nat Rev Gastroenterol Hepatol. 2010; 7(8):448-58. [PubMed: 20628345]

2. Parkin DM, Bray F, Ferlay J, et al. Global cancer statistics, 2002. CA Cancer J Clin. 2005; 55(2): 74-108. [PubMed: 15761078]

3. Bosch FX, Ribes J, Diaz M, et al. Primary liver cancer: worldwide incidence and trends. Gastroenterology. 2004; 127(5 Suppl 1):S5-16. [PubMed: 15508102]

4. Altekruse SF, McGlynn KA, Reichman ME. Hepatocellular carcinoma incidence, mortality, and survival trends in the United States from 1975 to 2005. J Clin Oncol. 2009; 27(9):1485-91. [PubMed: 19224838]

5. Armstrong GL, Alter MJ, McQuillan GM, et al. The past incidence of hepatitis C virus infection: implications for the future burden of chronic liver disease in the United States. Hepatology. 2000; 31(3):777-82. [PubMed: 10706572]

6. Ma WL, Hsu CL, Wu MH, et al. Androgen receptor is a new potential therapeutic target for the treatment of hepatocellular carcinoma. Gastroenterology. 2008; 135(3):947-55. 955, e941-5. [PubMed: 18639551]

7. Naugler WE, Sakurai T, Kim S, et al. Gender disparity in liver cancer due to sex differences in MyD88-dependent IL-6 production. Science. 2007; 317(5834):121-4. [PubMed: 17615358]

8. Yu MW, Chen CJ. Elevated serum testosterone levels and risk of hepatocellular carcinoma. Cancer Res. 1993; 53(4):790-4. [PubMed: 8381328]

9. El-Serag HB, Rudolph KL. Hepatocellular carcinoma: epidemiology and molecular carcinogenesis. Gastroenterology. 2007; 132(7):2557-76. [PubMed: 17570226]

10. Beasley RP. Hepatitis B virus. The major etiology of hepatocellular carcinoma. Cancer. 1988; 61(10):1942-56. [PubMed: 2834034]

11. Sherman M, Peltekian KM, Lee C. Screening for hepatocellular carcinoma in chronic carriers of hepatitis B virus: incidence and prevalence of hepatocellular carcinoma in a North American urban population. Hepatology. 1995; 22(2):432-8. [PubMed: 7543434]

12. Villeneuve JP, Desrochers M, Infante-Rivard C, et al. A long-term follow-up study of asymptomatic hepatitis B surface antigen-positive carriers in Montreal. Gastroenterology. 1994; 106(4):1000-5. [PubMed: 8143967]

13. Chen CJ, Liang KY, Chang AS, et al. Effects of hepatitis B virus, alcohol drinking, cigarette smoking and familial tendency on hepatocellular carcinoma. Hepatology. 1991; 13(3):398-406. [PubMed: 1847891]

14. Lu SN, Lin TM, Chen CJ, et al. A case-control study of primary hepatocellular carcinoma in Taiwan. Cancer. 1988; 62(9):2051-5. [PubMed: 2844388]

15. Yang HI, Lu SN, Liaw YF, et al. Hepatitis B e antigen and the risk of hepatocellular carcinoma. N Engl J Med. 2002; 347(3):168-74. [PubMed: 12124405] 
16. Chen CJ, Yang HI, Su J, et al. Risk of hepatocellular carcinoma across a biological gradient of serum hepatitis B virus DNA level. JAMA. 2006; 295(1):65-73. [PubMed: 16391218]

17. Liang TJ, Jeffers LJ, Reddy KR, et al. Viral pathogenesis of hepatocellular carcinoma in the United States. Hepatology. 1993; 18(6):1326-33. [PubMed: 8244256]

18. Chisari FV. Rous-Whipple Award Lecture. Viruses, immunity, and cancer: lessons from hepatitis B. Am J Pathol. 2000; 156(4):1117-32. [PubMed: 10751335]

19. Dandri M, Burda MR, Burkle A, et al. Increase in de novo HBV DNA integrations in response to oxidative DNA damage or inhibition of poly(ADP-ribosyl)ation. Hepatology. 2002; 35(1):217-23. [PubMed: 11786979]

20. Bonilla Guerrero R, Roberts LR. The role of hepatitis B virus integrations in the pathogenesis of human hepatocellular carcinoma. J Hepatol. 2005; 42(5):760-77. [PubMed: 15826727]

21. Ferber MJ, Montoya DP, Yu C, et al. Integrations of the hepatitis B virus (HBV) and human papillomavirus (HPV) into the human telomerase reverse transcriptase (hTERT) gene in liver and cervical cancers. Oncogene. 2003; 22(24):3813-20. [PubMed: 12802289]

22. Horikawa I, Barrett JC. cis-Activation of the human telomerase gene (hTERT) by the hepatitis B virus genome. J Natl Cancer Inst. 2001; 93(15):1171-3. [PubMed: 11481390]

23. Paterlini-Brechot P, Saigo K, Murakami Y, et al. Hepatitis B virus-related insertional mutagenesis occurs frequently in human liver cancers and recurrently targets human telomerase gene.

Oncogene. 2003; 22(25):3911-6. [PubMed: 12813464]

24. Yen TS. Hepadnaviral X protein: review of recent progress. J Biomed Sci. 1996; 3(1):20-30. [PubMed: 11725079]

25. Bouchard MJ, Wang LH, Schneider RJ. Calcium signaling by HBx protein in hepatitis B virus DNA replication. Science. 2001; 294(5550):2376-8. [PubMed: 11743208]

26. Chami M, Ferrari D, Nicotera $\mathrm{P}$, et al. Caspase-dependent alterations of $\mathrm{Ca} 2+$ signaling in the induction of apoptosis by hepatitis B virus X protein. J Biol Chem. 2003; 278(34):31745-55. [PubMed: 12799372]

27. Rahmani Z, Huh KW, Lasher R, et al. Hepatitis B virus X protein colocalizes to mitochondria with a human voltage-dependent anion channel, HVDAC3, and alters its transmembrane potential. J Virol. 2000; 74(6):2840-6. [PubMed: 10684300]

28. Branda M, Wands JR. Signal transduction cascades and hepatitis B and C related hepatocellular carcinoma. Hepatology. 2006; 43(5):891-902. [PubMed: 16628664]

29. Brechot C. Pathogenesis of hepatitis B virus-related hepatocellular carcinoma: old and new paradigms. Gastroenterology. 2004; 127(5 Suppl 1):S56-61. [PubMed: 15508104]

30. Alter MJ, Kruszon-Moran D, Nainan OV, et al. The prevalence of hepatitis C virus infection in the United States, 1988 through 1994. N Engl J Med. 1999; 341(8):556-62. [PubMed: 10451460]

31. Kiyosawa K, Tanaka E. Characteristics of hepatocellular carcinoma in Japan. Oncology. 2002; 62(Suppl 1):5-7. [PubMed: 11868786]

32. Donahue JG, Munoz A, Ness PM, et al. The declining risk of post-transfusion hepatitis C virus infection. N Engl J Med. 1992; 327(6):369-73. [PubMed: 1320736]

33. Schreiber GB, Busch MP, Kleinman SH, et al. The risk of transfusion-transmitted viral infections. The Retrovirus Epidemiology Donor Study. N Engl J Med. 1996; 334(26):1685-90. [PubMed: 8637512]

34. Lam JP, McOmish F, Burns SM, et al. Infrequent vertical transmission of hepatitis C virus. J Infect Dis. 1993; 167(3):572-6. [PubMed: 8382718]

35. Ohto H, Terazawa S, Sasaki N, et al. Transmission of hepatitis $\mathrm{C}$ virus from mothers to infants. The Vertical Transmission of Hepatitis C Virus Collaborative Study Group. N Engl J Med. 1994; 330(11):744-50. [PubMed: 8107740]

36. Sun CA, Wu DM, Lin CC, et al. Incidence and cofactors of hepatitis C virus-related hepatocellular carcinoma: a prospective study of 12,008 men in Taiwan. Am J Epidemiol. 2003; 157(8):674-82. [PubMed: 12697571]

37. Hassan MM, Hwang LY, Hatten CJ, et al. Risk factors for hepatocellular carcinoma: synergism of alcohol with viral hepatitis and diabetes mellitus. Hepatology. 2002; 36(5):1206-13. [PubMed: 12395331] 
38. Ikeda K, Marusawa H, Osaki Y, et al. Antibody to hepatitis B core antigen and risk for hepatitis Crelated hepatocellular carcinoma: a prospective study. Ann Intern Med. 2007; 146(9):649-56. [PubMed: 17470833]

39. Ohki T, Tateishi R, Sato T, et al. Obesity is an independent risk factor for hepatocellular carcinoma development in chronic hepatitis C patients. Clin Gastroenterol Hepatol. 2008; 6(4):459-64. [PubMed: 18387499]

40. Lok AS, Seeff LB, Morgan TR, et al. Incidence of hepatocellular carcinoma and associated risk factors in hepatitis C-related advanced liver disease. Gastroenterology. 2009; 136(1):138-48. [PubMed: 18848939]

41. Chen CL, Yang HI, Yang WS, et al. Metabolic factors and risk of hepatocellular carcinoma by chronic hepatitis B/C infection: a follow-up study in Taiwan. Gastroenterology. 2008; 135(1):11121. [PubMed: 18505690]

42. Pawlotsky JM. Genetic heterogeneity and properties of hepatitis C virus. Acta Gastroenterol Belg. 1998; 61(2):189-91. [PubMed: 9658605]

43. Lai MM, Ware CF. Hepatitis C virus core protein: possible roles in viral pathogenesis. Curr Top Microbiol Immunol. 2000; 242:117-34. [PubMed: 10592658]

44. Park JS, Yang JM, Min MK. Hepatitis C virus nonstructural protein NS4B transforms NIH3T3 cells in cooperation with the Ha-ras oncogene. Biochem Biophys Res Commun. 2000; 267(2): 581-7. [PubMed: 10631105]

45. Sakamuro D, Furukawa T, Takegami T. Hepatitis C virus nonstructural protein NS3 transforms NIH 3T3 cells. J Virol. 1995; 69(6):3893-6. [PubMed: 7745741]

46. Colombo M, de Franchis R, Del Ninno E, et al. Hepatocellular carcinoma in Italian patients with cirrhosis. N Engl J Med. 1991; 325(10):675-80. [PubMed: 1651452]

47. Tsukuma H, Hiyama T, Tanaka S, et al. Risk factors for hepatocellular carcinoma among patients with chronic liver disease. N Engl J Med. 1993; 328(25):1797-801. [PubMed: 7684822]

48. Donato F, Tagger A, Gelatti U, et al. Alcohol and hepatocellular carcinoma: the effect of lifetime intake and hepatitis virus infections in men and women. Am J Epidemiol. 2002; 155(4):323-31. [PubMed: 11836196]

49. Caballeria L, Pares A, Castells A, et al. Hepatocellular carcinoma in primary biliary cirrhosis: similar incidence to that in hepatitis C virus-related cirrhosis. Am J Gastroenterol. 2001; 96(4): 1160-3. [PubMed: 11316164]

50. Elmberg M, Hultcrantz R, Ekbom A, et al. Cancer risk in patients with hereditary hemochromatosis and in their first-degree relatives. Gastroenterology. 2003; 125(6):1733-41. [PubMed: 14724826]

51. Reddy A, Dash C, Leerapun A, et al. Hypothyroidism: a possible risk factor for liver cancer in patients with no known underlying cause of liver disease. Clin Gastroenterol Hepatol. 2007; 5(1): 118-23. [PubMed: 17008133]

52. Hassan MM, Kaseb A, Li D, et al. Association between hypothyroidism and hepatocellular carcinoma: a case-control study in the United States. Hepatology. 2009; 49(5):1563-70. [PubMed: 19399911]

53. Larsson SC, Wolk A. Coffee consumption and risk of liver cancer: a meta-analysis. Gastroenterology. 2007; 132(5):1740-5. [PubMed: 17484871]

54. El-Serag HB, Johnson ML, Hachem C, et al. Statins are associated with a reduced risk of hepatocellular carcinoma in a large cohort of patients with diabetes. Gastroenterology. 2009; 136(5):1601-8. [PubMed: 19208359]

55. Ni YH, Chang MH, Huang LM, et al. Hepatitis B virus infection in children and adolescents in a hyperendemic area: 15 years after mass hepatitis B vaccination. Ann Intern Med. 2001; 135(9): 796-800. [PubMed: 11694104]

56. Chang MH, Chen CJ, Lai MS, et al. Universal hepatitis B vaccination in Taiwan and the incidence of hepatocellular carcinoma in children. N Engl J Med. 1997; 336(26):1855-9. [PubMed: 9197213]

57. Chang MH, You SL, Chen CJ, et al. Decreased incidence of hepatocellular carcinoma in hepatitis B vaccinees: a 20-year follow-up study. J Natl Cancer Inst. 2009; 101(19):1348-55. [PubMed: 19759364] 
58. Lin SM, Sheen IS, Chien RN, et al. Long-term beneficial effect of interferon therapy in patients with chronic hepatitis B virus infection. Hepatology. 1999; 29(3):971-5. [PubMed: 10051505]

59. Papatheodoridis GV, Manesis E, Hadziyannis SJ. The long-term outcome of interferon-alpha treated and untreated patients with HBeAg-negative chronic hepatitis B. J Hepatol. 2001; 34(2): 306-13. [PubMed: 11281561]

60. van Zonneveld M, Honkoop P, Hansen BE, et al. Long-term follow-up of alpha-interferon treatment of patients with chronic hepatitis B. Hepatology. 2004; 39(3):804-10. [PubMed: 14999700]

61. Liaw YF, Sung JJ, Chow WC, et al. Lamivudine for patients with chronic hepatitis B and advanced liver disease. N Engl J Med. 2004; 351(15):1521-31. [PubMed: 15470215]

62. Matsumoto A, Tanaka E, Rokuhara A, et al. Efficacy of lamivudine for preventing hepatocellular carcinoma in chronic hepatitis B: a multicenter retrospective study of 2795 patients. Hepatol Res. 2005; 32(3):173-84. [PubMed: 16024289]

63. Yuen MF, Seto WK, Chow DH, et al. Long-term lamivudine therapy reduces the risk of long-term complications of chronic hepatitis B infection even in patients without advanced disease. Antivir Ther. 2007; 12(8):1295-303. [PubMed: 18240869]

64. Nishiguchi S, Shiomi S, Nakatani S, et al. Prevention of hepatocellular carcinoma in patients with chronic active hepatitis C and cirrhosis. Lancet. 2001; 357(9251):196-7. [PubMed: 11213099]

65. Camma C, Giunta M, Andreone P, et al. Interferon and prevention of hepatocellular carcinoma in viral cirrhosis: an evidence-based approach. J Hepatol. 2001; 34(4):593-602. [PubMed: 11394661]

66. Papatheodoridis GV, Papadimitropoulos VC, Hadziyannis SJ. Effect of interferon therapy on the development of hepatocellular carcinoma in patients with hepatitis $\mathrm{C}$ virus-related cirrhosis: a meta-analysis. Aliment Pharmacol Ther. 2001; 15(5):689-98. [PubMed: 11328263]

67. Bernardinello E, Cavalletto L, Chemello L, et al. Long-term clinical outcome after beta-interferon therapy in cirrhotic patients with chronic hepatitis C. TVVH Study Group. Hepatogastroenterology. 1999; 46(30):3216-22. [PubMed: 10626189]

68. Valla DC, Chevallier M, Marcellin P, et al. Treatment of hepatitis C virus-related cirrhosis: a randomized, controlled trial of interferon alfa-2b versus no treatment. Hepatology. 1999; 29(6): 1870-5. [PubMed: 10347132]

69. Yoshida H, Shiratori Y, Moriyama M, et al. Interferon therapy reduces the risk for hepatocellular carcinoma: national surveillance program of cirrhotic and noncirrhotic patients with chronic hepatitis C in Japan. IHIT Study Group. Inhibition of Hepatocarcinogenesis by Interferon Therapy. Ann Intern Med. 1999; 131(3):174-81. [PubMed: 10428733]

70. Di Bisceglie AM, Shiffman ML, Everson GT, et al. Prolonged therapy of advanced chronic hepatitis C with low-dose peginterferon. N Engl J Med. 2008; 359(23):2429-41. [PubMed: 19052125]

71. Zhang BH, Yang BH, Tang ZY. Randomized controlled trial of screening for hepatocellular carcinoma. J Cancer Res Clin Oncol. 2004; 130(7):417-22. [PubMed: 15042359]

72. Bolondi L, Sofia S, Siringo S, et al. Surveillance programme of cirrhotic patients for early diagnosis and treatment of hepatocellular carcinoma: a cost effectiveness analysis. Gut. 2001; 48(2):251-9. [PubMed: 11156649]

73. Trevisani F, De NS, Rapaccini G, et al. Semiannual and annual surveillance of cirrhotic patients for hepatocellular carcinoma: effects on cancer stage and patient survival (Italian experience). Am J Gastroenterol. 2002; 97(3):734-44. [PubMed: 11922571]

74. Saab S, Ly D, Nieto J, et al. Hepatocellular carcinoma screening in patients waiting for liver transplantation: a decision analytic model. Liver Transpl. 2003; 9(7):672-81. [PubMed: 12827551]

75. Trevisani F, D'Intino PE, Morselli-Labate AM, et al. Serum alpha-fetoprotein for diagnosis of hepatocellular carcinoma in patients with chronic liver disease: influence of HBsAg and anti-HCV status. J Hepatol. 2001; 34(4):570-5. [PubMed: 11394657]

76. Marrero JA, Feng Z, Wang Y, et al. Alpha-fetoprotein, des-gamma carboxyprothrombin, and lectin-bound alpha-fetoprotein in early hepatocellular carcinoma. Gastroenterology. 2009; 137(1): 110-8. [PubMed: 19362088] 
77. Burrel M, Llovet JM, Ayuso C, et al. MRI angiography is superior to helical CT for detection of HCC prior to liver transplantation: an explant correlation. Hepatology. 2003; 38(4):1034-42. [PubMed: 14512891]

78. Bruix J, Sherman M. Management of hepatocellular carcinoma. Hepatology. 2005; 42(5):1208-36. [PubMed: 16250051]

79. Durand F, Regimbeau JM, Belghiti J, et al. Assessment of the benefits and risks of percutaneous biopsy before surgical resection of hepatocellular carcinoma. J Hepatol. 2001; 35(2):254-8. [PubMed: 11580148]

80. Huang GT, Sheu JC, Yang PM, et al. Ultrasound-guided cutting biopsy for the diagnosis of hepatocellular carcinoma-a study based on 420 patients. J Hepatol. 1996; 25(3):334-8. [PubMed: 8895013]

81. Silva MA, Hegab B, Hyde C, et al. Needle track seeding following biopsy of liver lesions in the diagnosis of hepatocellular cancer: a systematic review and meta-analysis. Gut. 2008; 57(11): 1592-6. [PubMed: 18669577]

82. Vauthey JN, Ribero D, Abdalla EK, et al. Outcomes of liver transplantation in 490 patients with hepatocellular carcinoma: validation of a uniform staging after surgical treatment. J Am Coll Surg. 2007; 204(5):1016-27. [discussion: 1027-8]. [PubMed: 17481532]

83. The Cancer of the Liver Italian Program (CLIP) Investigators. Prospective validation of the CLIP score: a new prognostic system for patients with cirrhosis and hepatocellular carcinoma. Hepatology. 2000; 31(4):840-5. [PubMed: 10733537]

84. Ueno S, Tanabe G, Sako K, et al. Discrimination value of the new western prognostic system (CLIP score) for hepatocellular carcinoma in 662 Japanese patients. Cancer of the Liver Italian Program. Hepatology. 2001; 34(3):529-34. [PubMed: 11526539]

85. Marrero JA, Fontana RJ, Barrat A, et al. Prognosis of hepatocellular carcinoma: comparison of 7 staging systems in an American cohort. Hepatology. 2005; 41(4):707-16. [PubMed: 15795889]

86. Llovet JM, Bru C, Bruix J. Prognosis of hepatocellular carcinoma: the BCLC staging classification. Semin Liver Dis. 1999; 19(3):329-38. [PubMed: 10518312]

87. Bruix J, Castells A, Bosch J, et al. Surgical resection of hepatocellular carcinoma in cirrhotic patients: prognostic value of preoperative portal pressure. Gastroenterology. 1996; 111(4):101822. [PubMed: 8831597]

88. Llovet JM, Fuster J, Bruix J. Intention-to-treat analysis of surgical treatment for early hepatocellular carcinoma: resection versus transplantation. Hepatology. 1999; 30(6):1434-40. [PubMed: 10573522]

89. Teh SH, Christein J, Donohue J, et al. Hepatic resection of hepatocellular carcinoma in patients with cirrhosis: Model of End-Stage Liver Disease (MELD) score predicts perioperative mortality. J Gastrointest Surg. 2005; 9(9):1207-15. [discussion: 1215]. [PubMed: 16332475]

90. Ikai I, Arii S, Kojiro M, et al. Reevaluation of prognostic factors for survival after liver resection in patients with hepatocellular carcinoma in a Japanese nationwide survey. Cancer. 2004; 101(4): 796-802. [PubMed: 15305412]

91. Imamura H, Matsuyama Y, Tanaka E, et al. Risk factors contributing to early and late phase intrahepatic recurrence of hepatocellular carcinoma after hepatectomy. J Hepatol. 2003; 38(2): 200-7. [PubMed: 12547409]

92. Okada S, Shimada K, Yamamoto J, et al. Predictive factors for postoperative recurrence of hepatocellular carcinoma. Gastroenterology. 1994; 106(6):1618-24. [PubMed: 8194710]

93. Shi M, Guo RP, Lin XJ, et al. Partial hepatectomy with wide versus narrow resection margin for solitary hepatocellular carcinoma: a prospective randomized trial. Ann Surg. 2007; 245(1):36-43. [PubMed: 17197963]

94. Penn I. Hepatic transplantation for primary and metastatic cancers of the liver. Surgery. 1991; 110(4):726-34. [discussion: 734-5]. [PubMed: 1656538]

95. Ringe B, Pichlmayr R, Wittekind C, et al. Surgical treatment of hepatocellular carcinoma: experience with liver resection and transplantation in 198 patients. World J Surg. 1991; 15(2):27085. [PubMed: 1851588] 
96. Mazzaferro V, Regalia E, Doci R, et al. Liver transplantation for the treatment of small hepatocellular carcinomas in patients with cirrhosis. N Engl J Med. 1996; 334(11):693-9. [PubMed: 8594428]

97. Yao FY, Ferrell L, Bass NM, et al. Liver transplantation for hepatocellular carcinoma: expansion of the tumor size limits does not adversely impact survival. Hepatology. 2001; 33(6):1394-403. [PubMed: 11391528]

98. Chapman WC, Majella Doyle MB, Stuart JE, et al. Outcomes of neoadjuvant transarterial chemoembolization to downstage hepatocellular carcinoma before liver transplantation. Ann Surg. 2008; 248(4):617-25. [PubMed: 18936575]

99. Yao FY, Hirose R, LaBerge JM, et al. A prospective study on downstaging of hepatocellular carcinoma prior to liver transplantation. Liver Transpl. 2005; 11(12):1505-14. [PubMed: 16315294]

100. Yao FY, Kerlan RK Jr, Hirose R, et al. Excellent outcome following down-staging of hepatocellular carcinoma prior to liver transplantation: an intention-to-treat analysis. Hepatology. 2008; 48(3):819-27. [PubMed: 18688876]

101. Trotter JF, Wachs M, Everson GT, et al. Adult-to-adult transplantation of the right hepatic lobe from a living donor. N Engl J Med. 2002; 346(14):1074-82. [PubMed: 11932476]

102. Yao FY, Bass NM, Nikolai B, et al. Liver transplantation for hepatocellular carcinoma: analysis of survival according to the intention-to-treat principle and dropout from the waiting list. Liver Transpl. 2002; 8(10):873-83. [PubMed: 12360427]

103. Ishii H, Okada S, Nose H, et al. Local recurrence of hepatocellular carcinoma after percutaneous ethanol injection. Cancer. 1996; 77(9):1792-6. [PubMed: 8646676]

104. Livraghi T, Bolondi L, Lazzaroni S, et al. Percutaneous ethanol injection in the treatment of hepatocellular carcinoma in cirrhosis. A study on 207 patients. Cancer. 1992; 69(4):925-9. [PubMed: 1310435]

105. Vilana R, Bruix J, Bru C, et al. Tumor size determines the efficacy of percutaneous ethanol injection for the treatment of small hepatocellular carcinoma. Hepatology. 1992; 16(2):353-7. [PubMed: 1322349]

106. Lencioni RA, Allgaier HP, Cioni D, et al. Small hepatocellular carcinoma in cirrhosis: randomized comparison of radio-frequency thermal ablation versus percutaneous ethanol injection. Radiology. 2003; 228(1):235-40. [PubMed: 12759473]

107. Lin SM, Lin CJ, Lin CC, et al. Radiofrequency ablation improves prognosis compared with ethanol injection for hepatocellular carcinoma < or =4 cm. Gastroenterology. 2004; 127(6):171423. [PubMed: 15578509]

108. Chen MS, Li JQ, Zheng Y, et al. A prospective randomized trial comparing percutaneous local ablative therapy and partial hepatectomy for small hepatocellular carcinoma. Ann Surg. 2006; 243(3):321-8. [PubMed: 16495695]

109. Livraghi T, Meloni F, Di Stasi M, et al. Sustained complete response and complications rates after radiofrequency ablation of very early hepatocellular carcinoma in cirrhosis: Is resection still the treatment of choice? Hepatology. 2008; 47(1):82-9. [PubMed: 18008357]

110. Lau WY, Lai EC. The current role of radiofrequency ablation in the management of hepatocellular carcinoma: a systematic review. Ann Surg. 2009; 249(1):20-5. [PubMed: 19106671]

111. Chan AO, Yuen MF, Hui CK, et al. A prospective study regarding the complications of transcatheter intraarterial lipiodol chemoembolization in patients with hepatocellular carcinoma. Cancer. 2002; 94(6):1747-52. [PubMed: 11920537]

112. Llovet JM, Real MI, Montana X, et al. Arterial embolisation or chemoembolisation versus symptomatic treatment in patients with unresectable hepatocellular carcinoma: a randomised controlled trial. Lancet. 2002; 359(9319):1734-9. [PubMed: 12049862]

113. Lo CM, Ngan H, Tso WK, et al. Randomized controlled trial of transarterial lipiodol chemoembolization for unresectable hepatocellular carcinoma. Hepatology. 2002; 35(5):116471. [PubMed: 11981766] 
114. Takayasu K, Arii S, Ikai I, et al. Prospective cohort study of transarterial chemoembolization for unresectable hepatocellular carcinoma in 8510 patients. Gastroenterology. 2006; 131(2):461-9. [PubMed: 16890600]

115. Alba E, Valls C, Dominguez J, et al. Transcatheter arterial chemoembolization in patients with hepatocellular carcinoma on the waiting list for orthotopic liver transplantation. AJR Am J Roentgenol. 2008; 190(5):1341-8. [PubMed: 18430853]

116. Takaki H, Yamakado K, Nakatsuka A, et al. Radiofrequency ablation combined with chemoembolization for the treatment of hepatocellular carcinomas $5 \mathrm{~cm}$ or smaller: risk factors for local tumor progression. J Vasc Interv Radiol. 2007; 18(7):856-61. [PubMed: 17609444]

117. Yamakado K, Nakatsuka A, Ohmori S, et al. Radiofrequency ablation combined with chemoembolization in hepatocellular carcinoma: treatment response based on tumor size and morphology. J Vasc Interv Radiol. 2002; 13(12):1225-32. [PubMed: 12471186]

118. Shibata T, Isoda H, Hirokawa Y, et al. Small hepatocellular carcinoma: is radiofrequency ablation combined with transcatheter arterial chemoembolization more effective than radiofrequency ablation alone for treatment? Radiology. 2009; 252(3):905-13. [PubMed: 19567647]

119. Castrucci M, Sironi S, De Cobelli F, et al. Plain and gadolinium-DTPA-enhanced MR imaging of hepatocellular carcinoma treated with transarterial chemoembolization. Abdom Imaging. 1996; 21(6):488-94. [PubMed: 8875869]

120. Forner A, Ayuso C, Varela M, et al. Evaluation of tumor response after locoregional therapies in hepatocellular carcinoma: are response evaluation criteria in solid tumors reliable? Cancer. 2009; 115(3):616-23. [PubMed: 19117042]

121. Tezuka M, Hayashi K, Okada Y, et al. Therapeutic results of computed-tomography-guided transcatheter arterial chemoembolization for local recurrence of hepatocellular carcinoma after initial transcatheter arterial chemoembolization: the results of 85 recurrent tumors in 35 patients. Dig Dis Sci. 2009; 54(3):661-9. [PubMed: 18649138]

122. Geschwind JF, Salem R, Carr BI, et al. Yttrium-90 microspheres for the treatment of hepatocellular carcinoma. Gastroenterology. 2004; 127(5 Suppl 1):S194-205. [PubMed: 15508085]

123. Sangro B, Bilbao JI, Boan J, et al. Radioembolization using 90Y-resin microspheres for patients with advanced hepatocellular carcinoma. Int J Radiat Oncol Biol Phys. 2006; 66(3):792-800. [PubMed: 16904840]

124. Vente MA, Wondergem M, van der Tweel I, et al. Yttrium-90 microsphere radioembolization for the treatment of liver malignancies: a structured meta-analysis. Eur Radiol. 2009; 19(4):951-9. [PubMed: 18989675]

125. Roberts LR, Gores GJ. Hepatocellular carcinoma: molecular pathways and new therapeutic targets. Semin Liver Dis. 2005; 25(2):212-25. [PubMed: 15918149]

126. Llovet JM, Ricci S, Mazzaferro V, et al. Sorafenib in advanced hepatocellular carcinoma. N Engl J Med. 2008; 359(4):378-90. [PubMed: 18650514] 


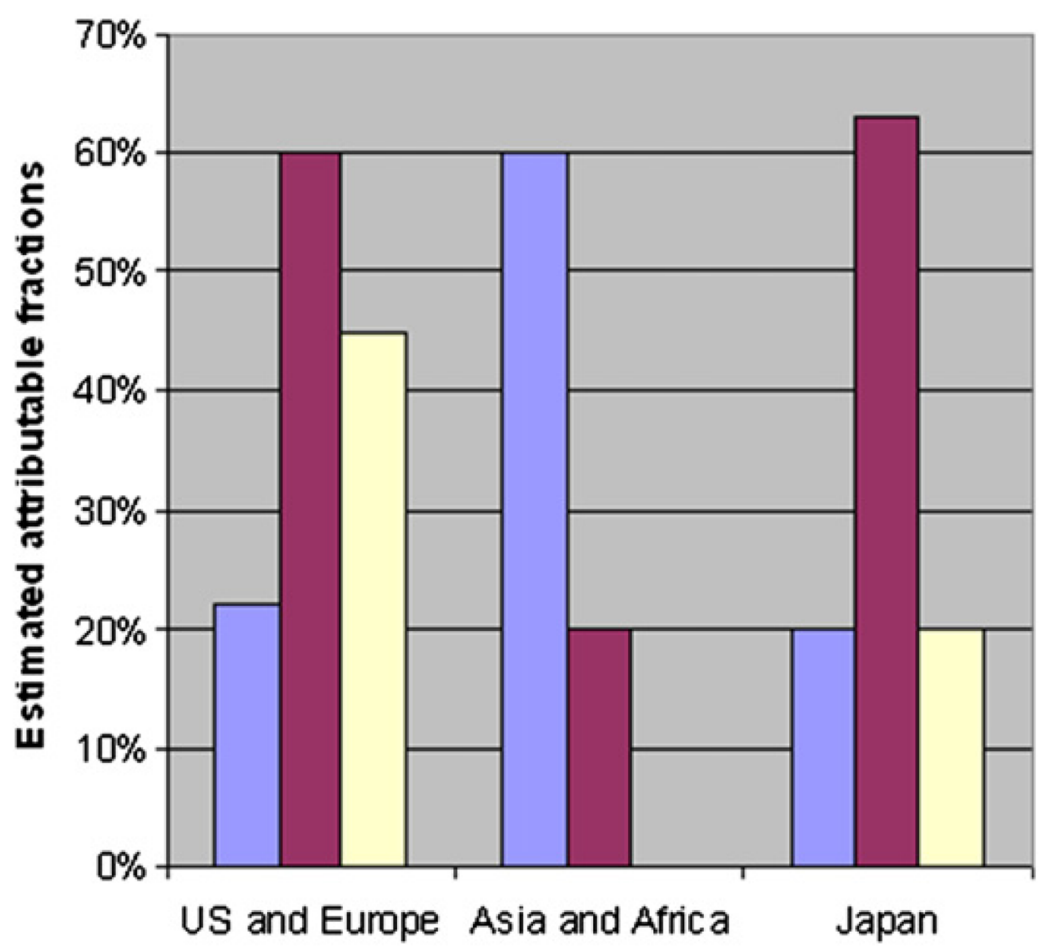

Fig. 1.

Risk factors of primary liver cancer and estimated attributable fractions in different parts of the world. (From Bosch FX, Ribes J, Diaz M, et al. Primary liver cancer: worldwide incidence and trends. Gastroenterology 2004;127:S5; with permission.) 


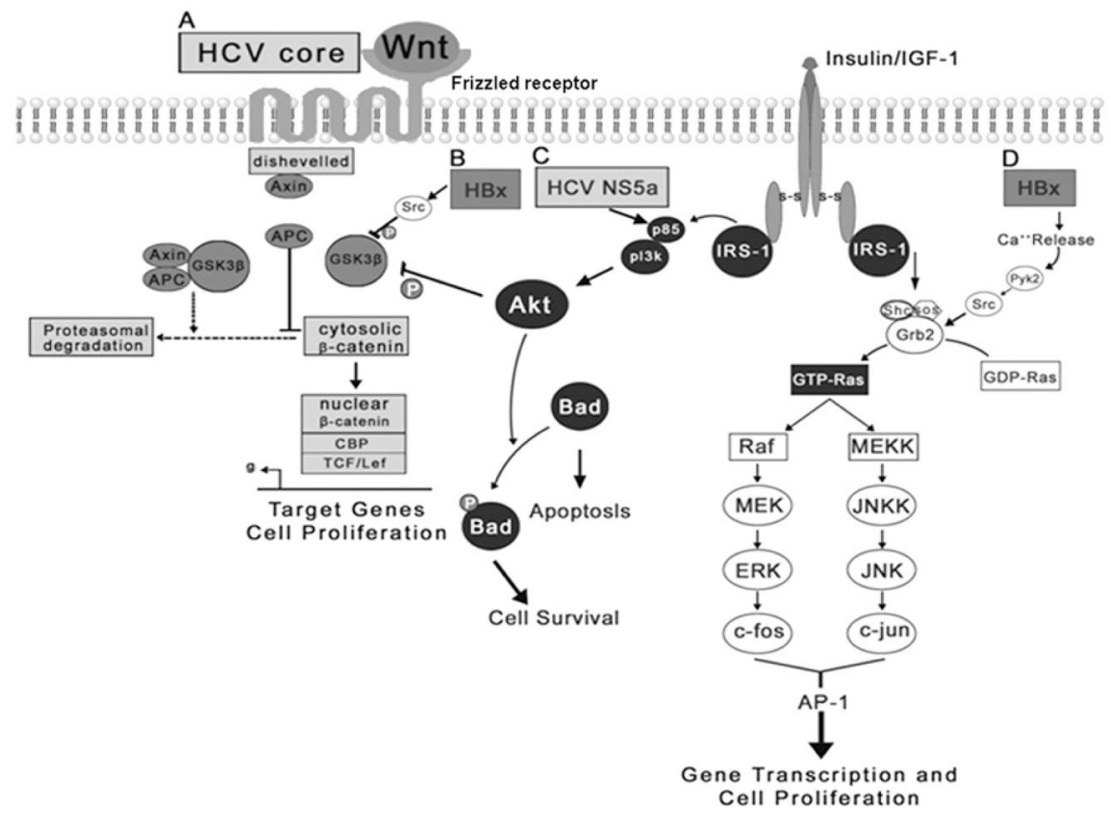

Fig. 2.

Two major signaling pathways activated by HBV and HCV in hepatocarcinogenesis. Cytosolic $\beta$-catenin is normally phosphorylated by a complex of adenomatous polyposis coli (APC), Axin, and glycogen synthase kinase $3 \beta(\mathrm{GSK} 3 \beta)$ and then degraded by the proteasome (dotted lines). Increased Wnt expression by HCV core protein activates Wnt/ $\beta$ catenin pathway. GSK3 $\beta$, APC, Axin complex is dissociated by Dishevelled and this results in the accumulation of cytosolic and nuclear $\beta$-catenin, which interacts with T-cell factor (TCF) and lymphoid enhancer binding protein (Lef), leading to the expression of target genes that stimulate liver cell proliferation. (A) HBx protein inactivates GSK3 $\beta$ via Src. This inactivation eventually results in the accumulation of nuclear $\beta$-catenin and increases the expression of genes involved in liver cell proliferation. (B) HCV NS5a protein interacts with p85. This interaction leads to the activation of Akt. Activated Akt phosphorylates Bad and decreases apoptosis of liver cells. At the same time, Akt phosphorylates GSK3 $\beta$, thereby preventing proteasomal degradation of $\beta$-catenin. $(C) \mathrm{HBx}$ protein increases the cytosolic calcium level, leading to activation of the Ras-Raf-ERK and Ras-MEKK-JNK cascades. AP-1, activator protein-1; ERK, extracellular signal-regulated kinase; IRS-1, insulin receptor substrate-1; JNK, jun, N-terminal kinase; PI3K, phosphatidylinositol-3 kinase. (Modified from Branda M, Wands JR. Signal transduction cascades and Hepatitis B and C related hepatocellular carcinoma. Hepatology 2006;43(5):891; with permission.) 


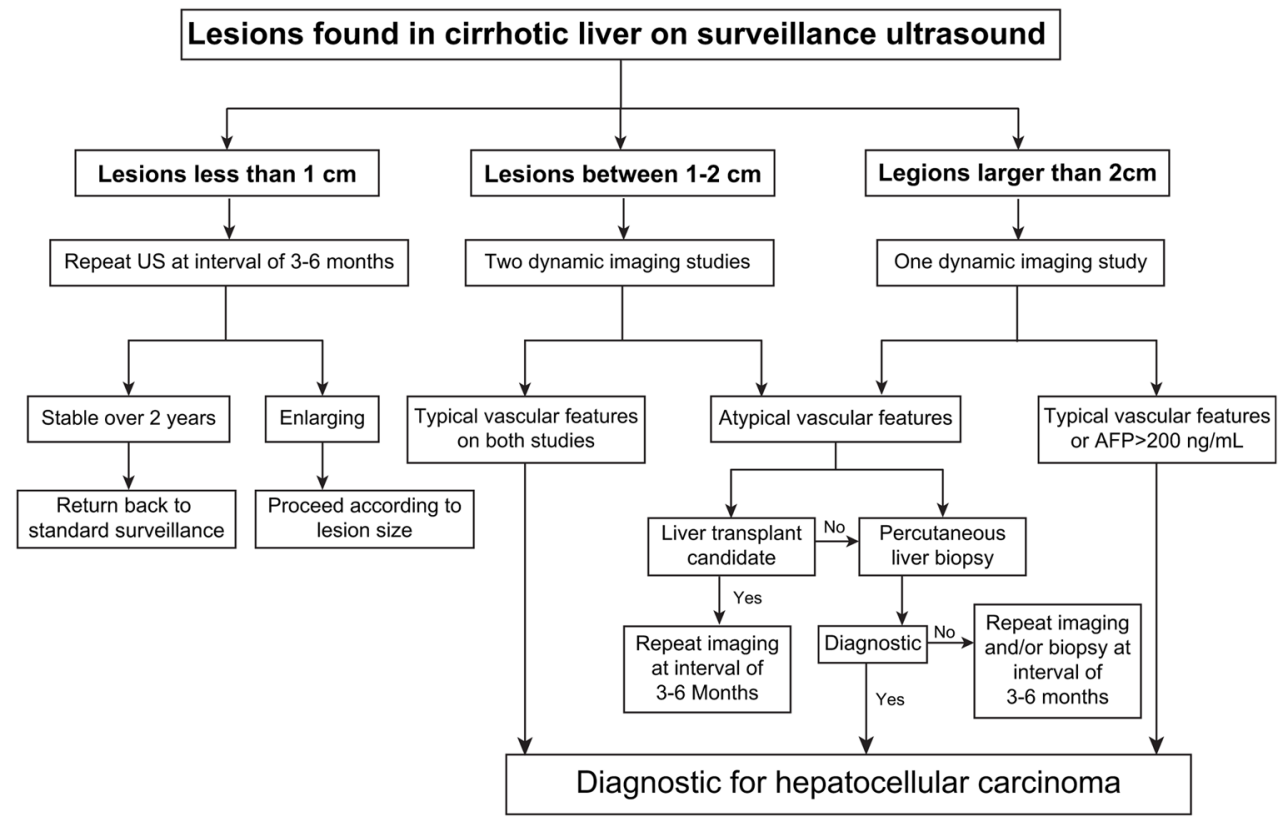

Fig. 3.

Algorithm for HCC diagnosis suggested by the American Association for the Study of Liver Disease. (Modified from Bruix J, Sherman M. Management of hepatocellular carcinoma. Hepatology 2005;42:1208; with permission.) 


\section{Curative treatment approach}

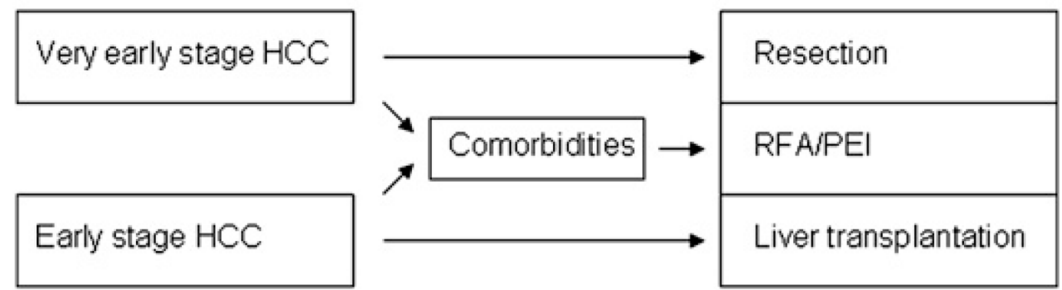

Palliative treatment approach

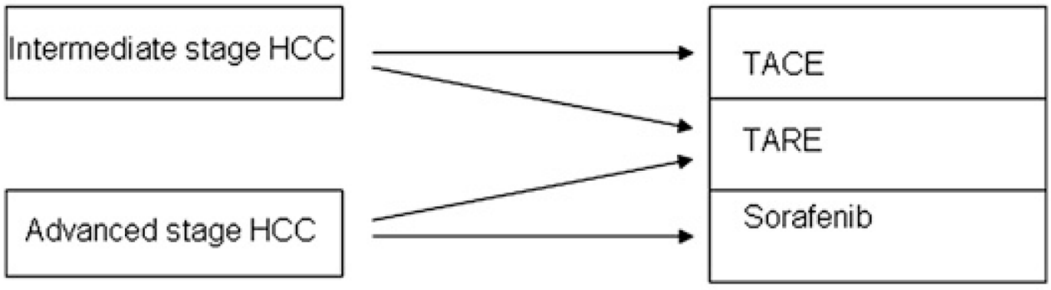

Comfort care

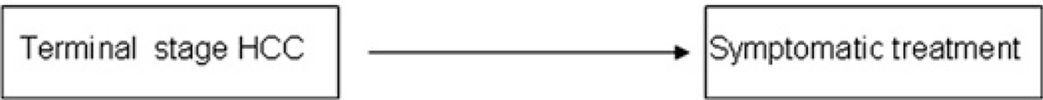

Fig. 4.

Treatment recommendation according to the modified BCLC staging classification. PEI, percutaneous ethanol injection; RFA, radiofrequency ablation; TACE, transarterial chemoembolization; TARE, transarterial radioembolization. 


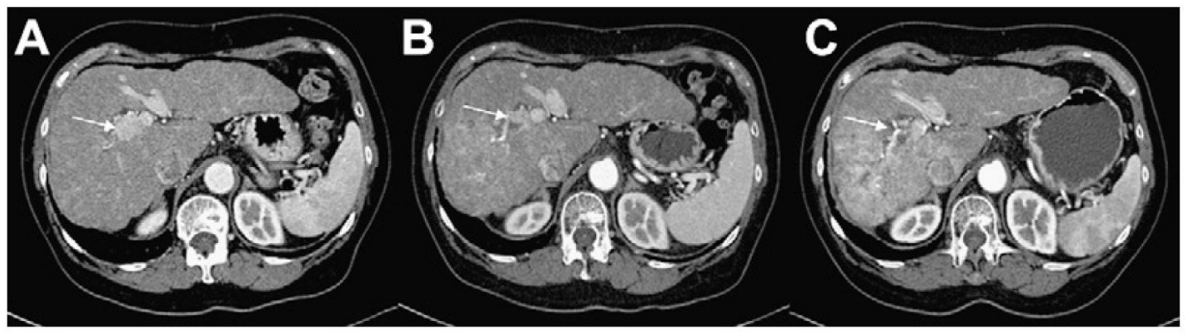

Fig. 5.

Treatment effect of radioembolization (TheraSphere treatment). (A) Contrast-enhanced CT of the abdomen with biphasic imaging of the liver found a $2.6 \times 1.9-\mathrm{cm}$ mass (white arrow) located near the portal vein bifurcation. This mass was treated with radioembolization because of the patient's older age, tumor location, and increased bilirubin. (B) One month after the treatment, the mass immediately adjacent to the right portal vein has decreased to $1.4 \mathrm{~cm}$ (white arrow). (C) Three months after the treatment, the previously noted hepatic mass adjacent to the right portal vein has decreased further in size (white arrow) and is difficult to differentiate from the background heterogeneous enhancement. Patient has survived for more than 3 years since the treatment without any evidence of recurrence. 


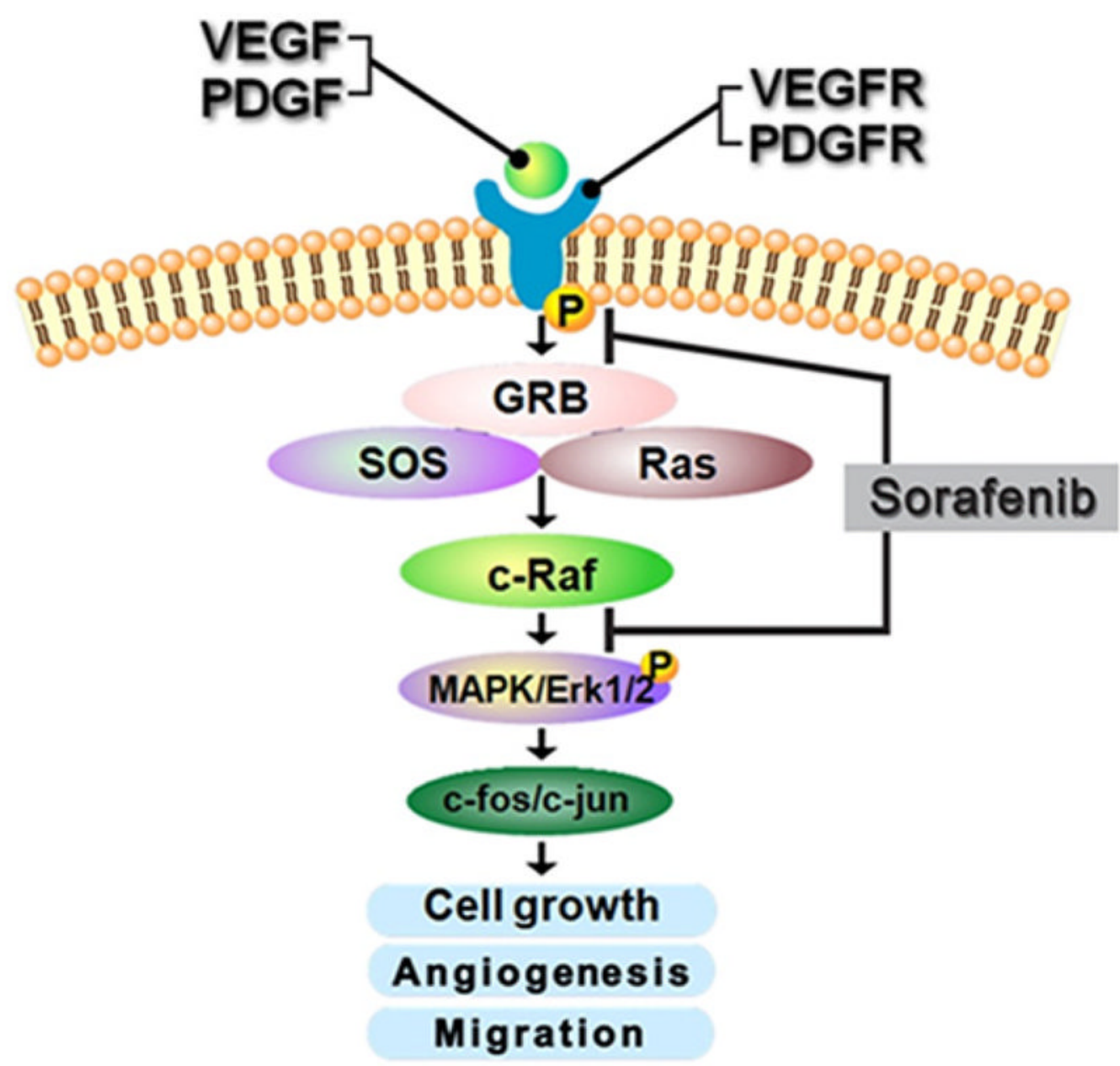

Fig. 6.

Mechanism of the antitumor effect of sorafenib. Sorafenib has dual antitumor effects. (1) Inhibition of vascular endothelial growth factor/platelet-derived growth factor signaling; (2) inhibition of Raf kinase- 1 activities. 
Table 1

Group of patients for whom surveillance is recommended

\begin{tabular}{|ll|}
\hline Hepatitis B Carrier & Cirrhosis from Other Causes \\
\hline Cirrhotic HBV carriers & Hepatitis C \\
\hline Family history of HCC & Alcoholic liver disease \\
\hline Africans $>20$ years old & Genetic hemochromatosis \\
\hline Asian men $>40$ years old & Primary biliary cirrhosis \\
\hline $\begin{array}{l}\text { Asian women }>50 \text { years old } \\
\text { High viral load (HBV DNA }>2000 \mathrm{IU} / \mathrm{mL}) \\
\text { High transaminases }\end{array}$ & $\begin{array}{l}\text { Potentially cirrhosis from any cause including nonalcoholic steatohepatitis, a1-antitrypsin } \\
\text { deficiency, autoimmune hepatitis }\end{array}$ \\
\hline
\end{tabular}



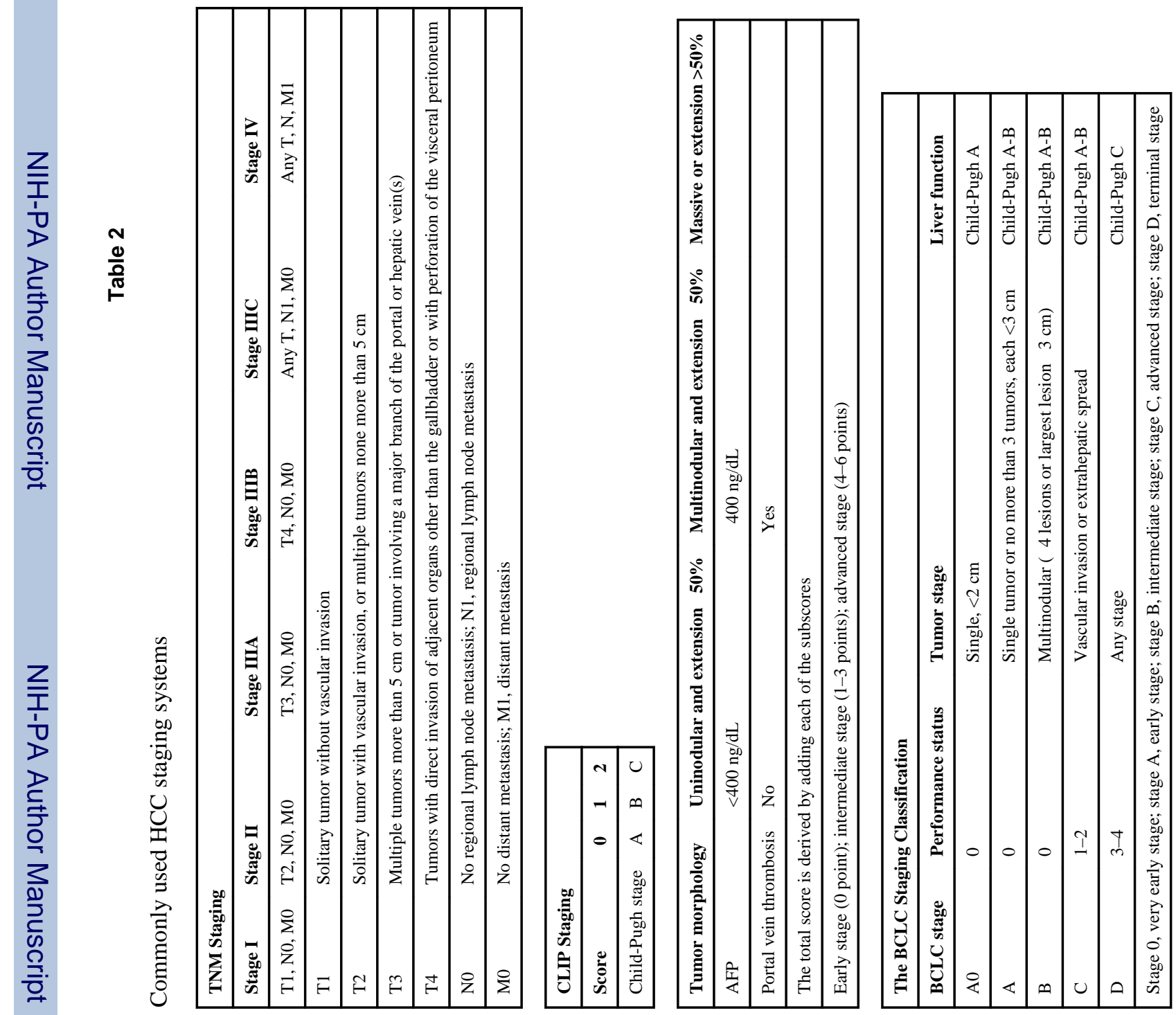

Infect Dis Clin North Am. Author manuscript; available in PMC 2014 March 12. 